First Peoples Child \& Family Review

A Journal on Innovation and Best Practices in Aboriginal Child Welfare Administration,

Research, Policy \& Practice

\title{
Finding Healing and Balance in Learning and Teaching at the First Nations University of Canada
}

\section{Erika Faith}

Volume 3, Number 4, 2007

URI: https://id.erudit.org/iderudit/1069369ar

DOI: https://doi.org/10.7202/1069369ar

See table of contents

Publisher(s)

First Nations Child and Family Caring Society of Canada

\section{ISSN}

1708-489X (print)

2293-6610 (digital)

Explore this journal

Cite this article

Faith, E. (2007). Finding Healing and Balance in Learning and Teaching at the First Nations University of Canada. First Peoples Child \& Family Review, 3(4), 8-12. https://doi.org/10.7202/1069369ar

\section{Article abstract}

In this personal memoir of three years teaching at the First Nations University of Canada, the author reflects on what she learned, in applying internally and externally, an Aboriginal model of social work education. As a person of non-Aboriginal ancestry, she explores how her own struggle with the imbalances inherent in academia spurred her search in grounding her teaching in holism, healing, reciprocal relationships, empowerment, liberation, and pleasure, and how the integration of these practices strengthened her relationships with her own spirit, but also with 'all my relations'.
This document is protected by copyright law. Use of the services of Érudit (including reproduction) is subject to its terms and conditions, which can be viewed online.

https://apropos.erudit.org/en/users/policy-on-use/ 


\title{
Finding Healing and Balance in Learning and Teaching at the First Nations University of Canada
}

\author{
Erika Faith
}

\section{Locating Myself Within Colonization and Social Work Education}

\author{
We of the empire world are caught at a fateful \\ moment. We are asking, we are learning, \\ digging through time and deep inside, crying, \\ hoping, inventing. And in this process of \\ homecoming, we are becoming fully human \\ (Glendinning, 2002: 172).
}

Graveline (1998) asserts that "resurrecting one's own history to find out how it has contributed to the history of the world" (p. 37) is essential to the process of all decolonization work. Imperialism, globalization, patriarchy, fundamentalism, and western rationality have created great imbalance and pain, both on a planetary level and in my personal life. As a forth-generation descendant of Scandinavian immigrants to Saskatchewan, Canada, and as a global citizen, my life work involves re-membering all that has been fractured by centuries of what Eisler (1987) refers to as 'dominator' ideologies and practices. The process of decolonization to me means to re-member and heal, returning to balance and wholeness the severed connections between body and spirit, between men and women, adults and children, between nations, and between human communities and all our nonhuman relations.

My whole life has been lived at the interface between colonizing and Indigenous ways of being in the world. As a child of missionary parents, I grew up in Nepal where the framework for my parents' presence was the belief that they were benefiting the local people with the technologies, systems, values, and Christian religion of the Western industrialized world. Upon my return to Canada, I had neither a sense of my own Indigenous

Questions or correspondence concerning this article may be addressed to:

erikafaith@sasktel.net

\begin{abstract}
In this personal memoir of three years teaching at the First Nations University of Canada, the author reflects on what she learned, in applying internally and externally, an Aboriginal model of social work education. As a person of non-Aboriginal ancestry, she explores how her own struggle with the imbalances inherent in academia spurred her search in grounding her teaching in holism, healing, reciprocal relationships, empowerment, liberation, and pleasure, and how the integration of these practices strengthened her relationships with her own spirit, but also with 'all my relations'.
\end{abstract}

Nordic roots nor the cultures and worldviews of the Indigenous Peoples of this land. From a deep yearning to find and know 'my place in this world', questions of identity and place, privilege and power, language and voice, harm and healing, have been woven throughout both my personal life and academic work.

Despite a few radical classes and educators, my experience of academia was largely of colonization and socialization within the dominant male-Euro-scientific paradigm. In my master's thesis I had critiqued the social work education system in which I had invested, as based on a parochial tradition, which became universalized through a larger project of Western imperialism ${ }^{1}$. While initially drawn to the ideal of 'helping people' (as most social work students are), during the course of my social work training, I became disillusioned with and cynical of the paternalism, moralism, and conservatism endemic in my chosen profession. As much of my life had been lived outside of Canada's borders, I wanted to learn from social work models that were not seeped in the Euro-WesternWhite tradition that I found so limiting. The ideals of education supporting liberation and enlightenment seemed at odds with the realities of how dominant education systems perpetuate various forms of oppression, imbalance, and domination (of positivist over experiential knowledge; of the cerebral over the spiritual, physical and emotional; 
of male over female, etc). I felt unable to resolve these contradictions within the 'mainstream' academic world.

By my late twenties, upon the completion of two social work degrees and a decade of intense academic, activist, and professional work in the field of social work and international development, I experienced a profound burn-out. The relentless drive that had led to my professional and academic successes had been fuelled by a deep sense of inadequacy; of never doing or being enough, a belief system stemming from childhood trauma, of which at the time I was unaware. Perfectionism, workaholism, and a focus on the intellect at the expense of the other aspects of my being, had left me exhausted and depleted, physically, emotionally, mentally and spiritually. I felt completely overwhelmed by feelings of tension and anxiety, and no longer experienced my former sense of passion and excitement about working toward all I believed in. To continue my professional work, I knew I needed an environment that would nourish my spirit and help me recreate a renewed relationship with education, activism, my profession, and most of all, between my own body, mind and spirit.

Academia was therefore the last place I expected to be able to find healing and wholeness, balance and recovery. And yet, in 2001 when I was offered a job teaching at the First Nations University of Canada ${ }^{2}$ I thought, "if there is any space in academia where the spiritual, emotional and physical can be integrated with the intellectual, it would be here", and so I accepted. At the First Nations University of Canada, not only was I given permission, but I was given a mandate that required me to ground all my work in partnership, balance, and spirituality. With a clear agenda of healing all that has been fractured by five hundred years of colonization, First Nations University of Canada, located in three cities in Saskatchewan, is a unique space where students and staff are invited to collectively engage in the project of transforming education from the oppressive and paternalistic 'banking model' described by Paulo Freire (2000), to one of decolonization, indigenization, politicization and liberation.

While for the past hundred years, Indian education has too often meant the education of Indians by non-Indians using non-Indian methods (Hampton, 1995: p.6), today many educational institutions across Canada are actively engaged in indigenizing curriculum and teaching methods. Conceived in the early 1970s, Canada's largest Indigenous university, grounded largely in the knowledge systems, cultures, and languages of the plains and woodlands peoples of Saskatchewan, is today at the cutting edge of the "change from accepting acculturation and cognitive assimilation as final ends to revitalizing and renewing languages and cultural identity and dignity" (Battiste \& Barman, 1995: p.xi).

\section{Learning and unlearning the role of educator}

We have a responsibility to participate in the struggle against the continuing effects of oppression, because effective teaching practice takes place in relationship with the teacher, student, family, school, community, as well as the broader society, keeping in mind that all of us are situated in, and affected by, the complex historical contexts of culture, race and class (Goulet, 2001,p.80).

Teaching post-secondary education is a weighty responsibility, intimidating perhaps to any initiate instructor. With the added mandate of integrating First Nations languages, knowledge systems, histories and healing traditions, I felt completely overwhelmed with the task before me. Without a native studies degree, without native ancestry myself, and without any formal preparation for university instruction, I felt completely inadequate and ill prepared for the task before me. I frequently dreamt that I was naked in front of students, for indeed I felt barely clothed by the flimsy credentials a master's degree in social work, and several years of professional work experience. Like most non-Aboriginal people of this land, I had almost no knowledge of the 'Indian country' into which I was now immersed. I knew little of the political systems and structures, cultures, languages, homelands, leaders or visionaries of the First Peoples of Saskatchewan.

During those first agonizing classes, my students and I peered at each other across the divide of differences; myself, the môniyâskwêsis (young European woman) professor, meeting my students, mostly nêhiyânâhk (of Cree language and territory), on average a decade older than me, in the formal setting of the classroom. It was the old story of the teacher coming from white academia and middle class privilege, while most of my students were coming from reserve communities, economic and social marginalization including direct experiences with the oppressions of the residential school system, the justice system, and the child welfare system. In one of my first classes, one of the students remarked aloud, "tânitê êtikwê ê-kî-miskawâcik ôhi okiskinwahamâkêwak" (I wonder where they find these teachers from!?) It's a good thing I didn't understand néhiyawéwin (Cree) at the time, for I might not have been able to go on with the class! Years later he and I would often joke about this first moment of encounter.

As I sought to practice liberation education according to the models of Jean Graveline (1998), bell hooks (1994), Paulo Freire (2000), and Eduard Lindeman (1961). I was alarmed to discover how deeply invested I was in the dominant model of education that I myself had struggled so much within! My own post-secondary learning had been as much about pain (fear, stress, anxiety, intense competition, feeling overwhelmed and personally disconnected), as the 
pure pleasure of learning. And while I had already spent considerable time deconstructing social work education as culturally biased in terms of dominant white/western/ academic systems of thinking, I continued to discover to my dismay, how much I had internalized and was indeed perpetuating, oppressive belief systems that I intellectually disagreed with! Although as a student I resented being swamped by information, feeling unable to digest it all, I would catch myself, in the name of 'academic rigor', pushing my students' limits of information intake, with beliefs such as "I had to suffer these dry readings so you should too", or the paternalistic "but it is good for you" (the same kind of rationalizations that perpetuates any form of oppression!).

Reflective journaling and conversations with colleagues were indispensable tools for the simultaneous learning and unlearning I was undertaking; of both constructing and deconstructing my role as educator. Through journal writing, I would identify incongruent beliefs and debilitating self-talk patterns based on fear, anxiety, inadequacy, and 'shoulds' derived from inherited notions of 'academic rigor.' I recognized that such fear-based beliefs, though unconscious, increased my sense of stress, thus negatively impacting my ability to engage authentically with students and colleagues. Having identified the fear-based beliefs, I would then create positive affirmations grounded in compassion and self-acceptance, knowing that the inner shifts would affect my outer behaviors.

When I felt overwhelmed with all that I believed I 'should' know and be, I would remind myself that my role as teacher is not so much to be an expert, but rather to learn together with students, and that authentic knowledge comes from integrated experience rather than stuffing heads (mine or theirs) with reams of information. As David Hannis notes in his memoir of teaching in an Aboriginal Albertan community, "An effective teacher is a mentor who acts rather as a midwife, drawing forth the knowledge that lies buried within, in a safe and supportive way" (Hannis, 1993, p.51). My colleagues would remind me about the importance of bringing my whole self to connect with my students as whole people. I would also paraphrase in my mind the words of the apostle Paul, taught to me in my childhood; "even if I have great knowledge, extensive experience, but have not love, these things will profit me (or my students) nothing."

\section{Exploring tools for transformation}

Can we, as adult educators, permeate the invisible barriers that keep people of different cultures from "connecting"? Can we somehow move from trepidation to trust, from fear to comfort, from misunderstanding to truth? Are we able to live a philosophy that allows the sharing of our different cultures in such a way that it enhances each of our paths? (Sanderson, 1996, p. 2)

Knowing I needed all the help I could get, I took every opportunity to nourish myself with the various ceremonies, teachings, and guidance offered by the Elders in our program. Because the practice of teaching 'from head to head' had left me disconnected from my emotions and spirituality, I knew that I needed to create a classroom space in which spirituality is included, learning is collective, and hierarchies between professor and student are minimized, so that the whole being of each person, including myself, was nurtured. Early in my teaching, at the direction of an Elder, I began to practice opening each class with a smudging ceremony, led by one of my students, with the intention of creating space to center, clear, and ground ourselves.

Jean Graveline, author of Circle Works: Transforming Eurocentric Consciousness, asserts that the role of teacher is healer, and reminds us that healing means to restore to wholeness. If our dominant education system has suffered from fracturing knowledge into minute areas of specialization, and from separating mind from body, spirit and emotions, liberation education must heal these splits. Both Graveline (1998) and hooks (1994) purport that education as healing practice requires creating a classroom space in which learning is pleasurable, stimulating, and empowering; a place where we connect with our spark, desire and passion. Having structured most of my life according to 'shoulds' and rigorous self-discipline, I found this new conceptualization of excellence both deeply unsettling and exciting. Can I really trust my attractions to lead to excellence? What if I miss important content? What does excellence and 'rigor' mean in the context of Indigenous social work education? As I continued to explore these questions, I was discovering that the more I could release my own need for control, and the more I could 'go with the flow', by teaching from a sense of pleasure and intuition, my teaching was enhanced rather than compromised.

The practice of investing time outside of the classroom in building relationships with students was not only one of the richest and most pleasurable aspects of my job, but also, from my perspective, a key aspect of practicing decolonizing education. Where most universities are nervous about personal contact between staff and students as a problematic 'boundary issue', at our small Saskatoon campus with a student body of only 350 , personal contact was institutionally supported and encouraged. Students and staff mixed together freely in the small cafeteria, outside on the 'smoker's deck', in the halls, and at ceremonies. At Round Dances in the winter 


\section{First Peoples Child \& Family Review, Volume 3, Number 4, 2007}

months we held hands and danced in spiraling circles until the wee hours of the morning. On weekends, the roles of student and teacher reversed when I attended a Sweat-Lodge ceremony conducted by one of my students, where our most intimate selves were shared, pain released and healing sought. At culture camp, an intensive ten-day course on Saskatchewan's Indigenous cultures held on reserve land, we sat together under the shade of a poplar arbor, listing to the teachings of the Elders, participating in sacred ceremonies, learning traditional crafts and survival skills, and cooking meals together over an outdoor stove.

My students became my teachers in powerful ways. Leading by example, they taught me how to integrate humor and modeled what it means to share deeply from our life stories. In opening their lives to me, they shared their pain; their experiences of various forms of abuse, of the residential schools, of life on reserves, on the streets, of incarceration; as well as their love for their children and grandchildren, their passion for healing, and desire to give back to their communities, the strength of their ceremonial traditions, and what being in the social work program meant to them. Inspired and humbled, I in turn, began to take more risks in sharing from my own life; of coming from a missionary family, of being a survivor of sexual abuse, and of my own cultural identity struggles. In conversations with my students, we were peers, no longer constrained by our institutionally designated roles of teacher and student. As we shared from our personal lives, a deep bond was established, a bond that transcended our differences.

\section{Conclusion}

We all have an indigenous mind. No matter where we live now, we all come from ancestors who ... originally saw the world as enchanted ... as a joyful, sentient organism in which all things were alive and capable of connecting with us ... We can find [our indigenous mind] again by discovering and appreciating the surviving indigenous cultures of the world in all their richness, depth, and wisdom (Pearsall, 1996, p.70).

As one year of teaching folded into two, then three, I came to understand that my own healing and liberation was inextricably woven together with the healing and liberation of my students. I saw that I had come to the First Nations University of Canada as much to learn as to teach; to help as to be helped; to give as to receive; to encourage and empower as to be encouraged and empowered. During my time at the First Nations University of Canada, I have become increasingly aware of how much of my own ancestral tribal knowledge had been lost to me, and I came to realize that the project of decolonization is global and requires all of us, regardless of where we sit on the colonizer/colonized continuum. Through mutual liberation, we are able to find hope for our communities, nations and our planet. My experience of learning and teaching at the First Nations University of Canada helped me to find 'my place in this world' among those who are working toward healing and recovery of balance, on a personal, community, regional, national and planetary level, and for this opportunity, I will be forever grateful.

\section{Endnotes}

1. Haug,E. (2001) 'Writings in the Margins: Critical Reflections on the Emerging Discourse of International Social Work'. Masters thesis, Department of Social Work, University of Calgary, Alberta, Canada.

2. Known until 2004 as the "Saskatchewan Indian Federated College."

\section{References}

Arden, H. (Ed.) (1994). Noble Red Man: Lakota Wisdomkeeper Mathew King. Hillsboro, Oregon: Beyond Words Publishing, Inc.

Battiste, M. \& Barman, J. (1995). First Nations Education in Canada: The Circle Unfolds. Vancouver: UBC Press.

Freire, P. (2000). Pedagogy of the Oppressed. New York: Continuum.

Glendinning, C. (2002). Off the Map: an Expedition Deep into Empire and the Global Economy. Gabriola Island, BC: New Society Publishers.

Goulet, L. (2001). Two Teachers of Aboriginal Students: Effective Practice in Sociohistorical Realities. In Canadian Journal of Native Education, volume 25, number 1.

Graveline, F. J. (1998). Circle Works: Transforming Eurocentric Consciousness. Halifax: Fernwood Publishers.

Hampton, E. (1995). Towards a Redefinition of Indian Education. In Battiste, M. \& Barman, J. (Eds.) First Nations Education in Canada: The Circle Unfolds. Vancouver: UBC Press.

Hannis, D. (1993). Liberation or assimilation; what are adult educators trying to do? In Feehan, K. \& Hannis, D. (Eds), From Strength to Strength: Social Work Education and Aboriginal People. Edmonton: Grant MacEwan Community College.

Haug,E. (2001). Writings in the Margins: Critical Reflections on the Emerging Discourse of International Social Work. ' Masters thesis, Department of Social Work, University of Calgary, Alberta, Canada.

hooks, b. (1994). Teaching to Transgress: Education as the Practice of Freedom. New York: Routledge.

Lindeman, E. (1961). The Meaning of Adult Education. Toronto: Harvest House. 


\section{Finding Healing and Balance in Learning and Teaching at the First Nations University of Canada}

Pearsall, P. (1996). The Pleasure Prescription: To Love, to Work, to Play-Life in the Balance. Alameda, California: Hunter House Inc.

Sanderson, J. (1996). Aboriginal Pedagogy: An Adult

Education Paradigm. Master's Project, Department of Communication, Continuing and Vocational Education, University of Saskatchewan, Saskatoon. 